\title{
Community's Perceptions on Their Own Environment toward Disaster Mitigation and Prevention: A Case Study of Menteng Atas - Jakarta, Indonesia
}

\author{
Danto Sukmajati and Edy Muladi \\ Department of Architecture, Mercu Buana University, Jakarta, Indonesia
}

\begin{abstract}
Menteng Atas is a sub district (Kelurahan) in Southern Jakarta - Indonesia, under the district (Kecamatan) of Setiabudi. As a common crowded settlement in urban area, this location facing multi problems related to physical environment. Built environment with very high density and not well-arranged of fronts and position, also do not meet standards of healthy construction and environment are the main problems of Menteng Atas that brings to disasters such as flooding and fire. This paper explored how members of Menteng Atas community perceive their everyday surroundings within the context of an environment that has rapidly changed, primarily due to urban development. This paper also discuss how far they aware about their environment, the disasters prevention, and what they wants for the future of their environment. The study was start from the inside of the local community. Symbolic communication varies from one situation to the next were founded by studying the accounts, explanations, and social action that are meaningful to a group of people. This paper is trying to present and identify perception of host community on their own environment especially related to disasters prevention, and end up with some recommendations to achieve sustainable housing and settlement at this area.
\end{abstract}

Key words: Built environment, perception, local community, disaster prevention.

\section{Introduction}

Urban slum area with its dense population and buildings and insufficient and below standard facilities and infrastructures are very vulnerable to flood and fire disasters. Domination of illegal settlers occupying the slump area becomes a driving factor of disaster. As the illegal settlers usually have low environmental concern. Fast growing and evolving Jakarta city development needs sufficient facilities and infrastructure.

Process of housing as a commodity has eliminated natural process between human and their settlement. Community improvement or development becomes a main concern in a housing and settlement area arrangement process. While housing and settlement management process conducted by its community members are used as an instrument for the community

Corresponding author: Danto Sukmajati, research fields: housing \& settlement. E-mail: danto@mercubuana.ac.id. development. By considering this instinctive relations and placing housing and settlement development as a strategic instrument to build community, then the housing area arrangement should put the residents and families from local residents in the center of long term and comprehensive solution development process. According to Moh. Jehansyah Siregar [1], housing and settlement physical environment's improvement and development are initial step in community development process. It is believed that improvement and development process driven by the community may become an effective instrument to bring in change in to community structure, farther change from merely physical change limit and guarantee to be settled. This matter is confirmed by Healey et al. [2], which is a main shift in planning, in public sector (government) as a main actor to active collaboration among elements in society. Economic consideration becomes a dominant element, where this drives the shift from role of 
Government as allocation and regulation maker to be more proactive (in term of stimulating development).

Kelurahan (Sub-District) Menteng Atas, South Jakarta is not spared from the rapid growth and development of slum settlement that formed by urban community (Fig. 1). This paper is discussing perception of host community on their own environment especially related to disasters prevention. Data, analysis, and discussions on this paper are part of study on housing improvement program on slum area in Menteng Atas was conducted on 2009.

\section{Method}

The study was conducted by qualitative method with semi grounded research technique. As mentioned by Rudito and Famiola [3], imbalances action as uncommon patterns of society will appear by observing social problems.

Moreover, the description of social living can be clearly and functionally identified from the existing system that applying before [3, 4]. According to Stark and Roberts [5], an unstructured observation is a field research method, by informal observation, often impromptu, and usually is recorded in a narrative fashion. Information as primary data shall be searched and collected through opinion expressions, and discussion. The opinion expression (brainstorming) aims at reviewing social ideas and aspiration for environmental betterment and planning.

The field observation is implemented in self-help manner into the location with unstructured interview - a short interview with several local inhabitants and social figures in the study location. Through such activities and other support-data, one gets an illustration of the local citizens and their environment. Visual observation is not related only to physical condition but also that of the target community. In man environment approach, it is clearly identified that any physical formation serves a reflection of social values that affects the local inhabitants. Discussion with the

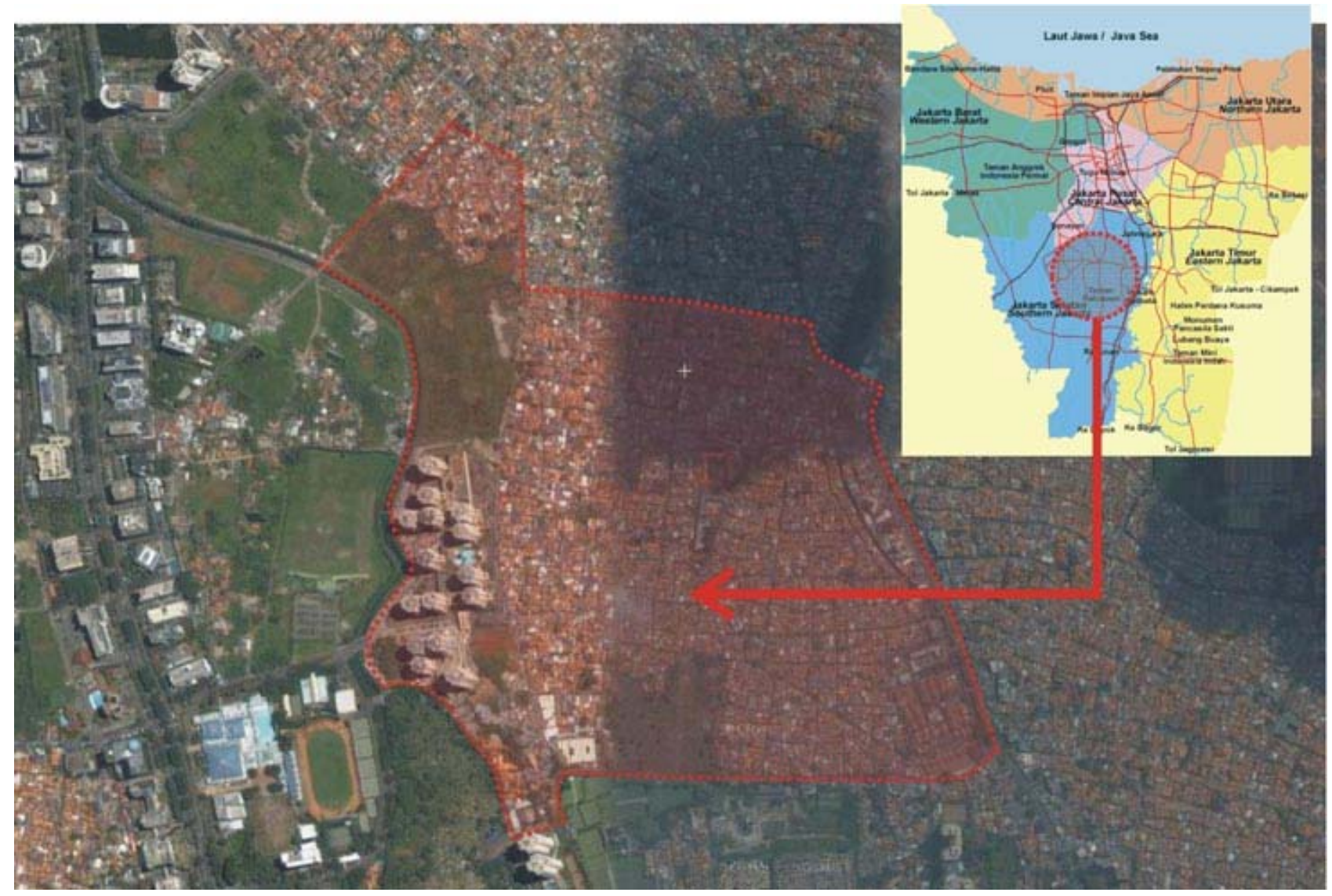

Fig. 1 Location of Menteng Atas. 
local inhabitants is held in non-formal and easy setting for their perception about their environment. The discussion is organized at every neighborhood units (RW). This activity is attended by $R W$ administrators, representatives from any $R T$ (Households), anggota Dewan Kelurahan (members of district representatives), and the head of informal society associations that identified as a potential group inside the society.

\section{Menteng Atas: Overview and Analysis}

Kelurahan (Subdistrict) Menteng Atas located in Kecamatan Setiabudi District South Jakarta with area of 90.45 hectares divided into 146 RT (Neighborhood Units) and 11 RW (Community Units). Menteng Atas bordered with Kelurahan Pasar Manggis in the North, Kelurahan Manggarai Selatan in the East, Kelurahan Menteng Dalam in the South, and Kelurahan Karet in the West. Most of its area is resident settlement, with detail $85 \%$ is used for housing housing and yards, $10 \%$ for Charitable Lands and Graveyard and 5\% for Industry and Convection. Its populaiton density rate is 371,464 per Hectare. Composition of productive age (20-55 years old) dominates by more than $50 \%$ of total population with comparision number of males and females is blanced. Majority work in trading sector and construction and the remaining works in service sector. Most residents embrace Islam religion (90\%). Most status of the land in study location is state-owned and other status. From demography's point of view Menteng Atas has population number potential dominated by productive age group, but in other side number of unemployed residents or those with non permanent job also remains high. The seasonal settlers are also high as indicated by growing boarding houses. Informal sector, taking advantage of lands under its control or even limited public space for a wide variety of business types. $80 \%$ residents have been living in this location for more than 20 years. Acquisition on the land is by inheriting the land generation by generation for such term. Some illegal housings also emerge in some locations. One of them on the Budhist/Christian graveyard directly bordered with settlement at RW 13 . Menteng Atas has community's characteristic namely easy to persuade to cooperate with programs involving them, in addition strong resilience is characterized with high enough social and cultural activities.

From field observation, at the study location can be found urbanism symptom that referred by Louis Wirth [6] as having a characteristic of transiensi or tendency that urban residents do not know all people in their settlement environemnt as the settlement is growing to become human crowd, crowded so then they do not know each other. In such condition every urban residents then moves or conduct activities among other urban residents without feeling embarassment, as according to them the activities are their own business and do not involve other urban residents' emotion or feeling or in broader meaning the urban public. The absence of social control due to this transiency condition results in public spaces where their utilization control are held by public experiences reduction due to utlization by certain parties arbitrarily for their personal interest or groups collectively with characteristic ignoring legal norms both normative and appplicable social law.

In Menteng Atas there are two characteristic groups of building conditions, namely building characteristic in first-tier wihich is easy to access and close to main road and building characteristic located at the center of location and rather difficult to access from main road (Table 1).

Building physical conditions directly related to collective road and in general its environment located in good, sufficient and standardized building feasibility. Dominated by permanent buildings. Well-organized with low building density. The existing allotments are for building, public facilities, government buildings, and well-ordered housing complex (not kampong) with sufficient facilities. This condition only covers small part of Menteng Atas area. In contrast to the first condition, buildings located in center of location are 
Table 1 Building characteristic on Menteng Atas.

\begin{tabular}{ccccc}
\hline RW & $\begin{array}{c}\text { Permanent } \\
\text { buildings }\end{array}$ & $\begin{array}{c}\text { Non/Semi } \\
\text { permanent } \\
\text { buildings }\end{array}$ & $\begin{array}{c}\text { High } \\
\text { density }\end{array}$ & $\begin{array}{c}\text { Low } \\
\text { density }\end{array}$ \\
\hline 02 & $\sqrt{ }$ & $\sqrt{ }$ & \\
\hline 04 & $\sqrt{ }$ & $\sqrt{ }$ & \\
\hline 05 & $\sqrt{ }$ & $\sqrt{ }$ & \\
\hline 06 & $\sqrt{ }$ & $\sqrt{ }$ & $\sqrt{ }$ \\
\hline 07 & $\sqrt{ }$ & $\sqrt{ }$ & $\sqrt{ }$ \\
\hline 08 & $\sqrt{ }$ & $\sqrt{ }$ & \\
\hline 09 & $\sqrt{ }$ & $\sqrt{ }$ & \\
\hline 12 & $\sqrt{ }$ & $\sqrt{ }$ & \\
\hline 13 & $\sqrt{ }$ & $\sqrt{ }$ & \\
\hline 14 & $\sqrt{ }$ & & $\sqrt{ }$ & $\sqrt{ }$ \\
\hline 15 & $\sqrt{ }$ & &
\end{tabular}

dominated by buildings with characteristic of very densed settlement linked with path/MTH which mostly do not meet the health standard. The high building density and their building's fronts and regularity are not patterned well. Most existing buildings are 2-floor buildings, particularly new buildings. The existing settlements are not equipped with sufficient environmental facilities and infrastructures.

Only around 20\% from entire location which can be reached by four-wheeled vehicles. In study location only small part served by local/environment road class with ROW 3-5 meters and the remaining only linked by narrow alleys. Such existing condition is very worrying, particularly related to emergency conditions such as fire, flood or other disaster. Such access condition certainly would hinder firefighting vehicles and ambulance to reach the location. The most vital of Kelurahan Menteng Atas that there is no any firefighting post at the location. With the existing building density, need for fire handling facilities becomes an absolute requirement, in addition it would be better if at study location minimum is established a good access which can be used anytime for emergency condition or fire. For that, it needs area of minimum $300 \mathrm{~m}^{2}$ (Fig. 2).

Related to flood disaster in urban areas, there are two that mostly related namely drainage system and garbage management (Table 2). At Menteng Atas main drainage system is divided into two main locations, namely East side at parts in alignment with Jl. Dr. Sahardjo and Jl. Minangkabau, and in West side namely Kali Cideng. While secondary drainage network encircling area of Kelurahan Menteng Atas and in East side of the area. In the study location, not all RW has well-planned garbage disposal. One of them is at RW 13, which currently made Buddhist/Christian graveyard area as garbage disposal. While part of other residents' household garbage are collected and disposed to other area.

Analysis is also conducted at each neighborhood unit (RW) toward 3 fundamental principles on zone planning namely physical quality of zone, characteristics and social structure, and opportunity of economic development. Rating scale 1 (very bad) to 5 (very good) is used. Conclusions drawn are:

- Physical Conditions of Zone on average are in sufficient conditions, only at RW 13 having special condition below average.

- Communal social conditions in study location is characterized by non formal social institution but degradate due to urban community growth characterized by transiency/unanomity among urban residents particularly at RW 13 .

Economic opportunity of residents in study area is good enough both considering the location directly bordered with urban commercial area.

\section{Menteng Atas and Residents Perception}

From above description and analysis, it can be concluded that Kelurahan Menteng Atas with its various environmental issues is very vulnerable toward flood and fire disasters. Next step, this study tries to see perception of local residents concerning the phenomena. In order to know perception of residents, some open questions are raised concerning their response toward environmental issues and potential where they live, either related to physical environmental, social culture or economic. The 
previous analysis results concluded that Menteng Atas has fire and blood disaster high level was not presented to them in order to guarantee their answers were not biased or artificial.
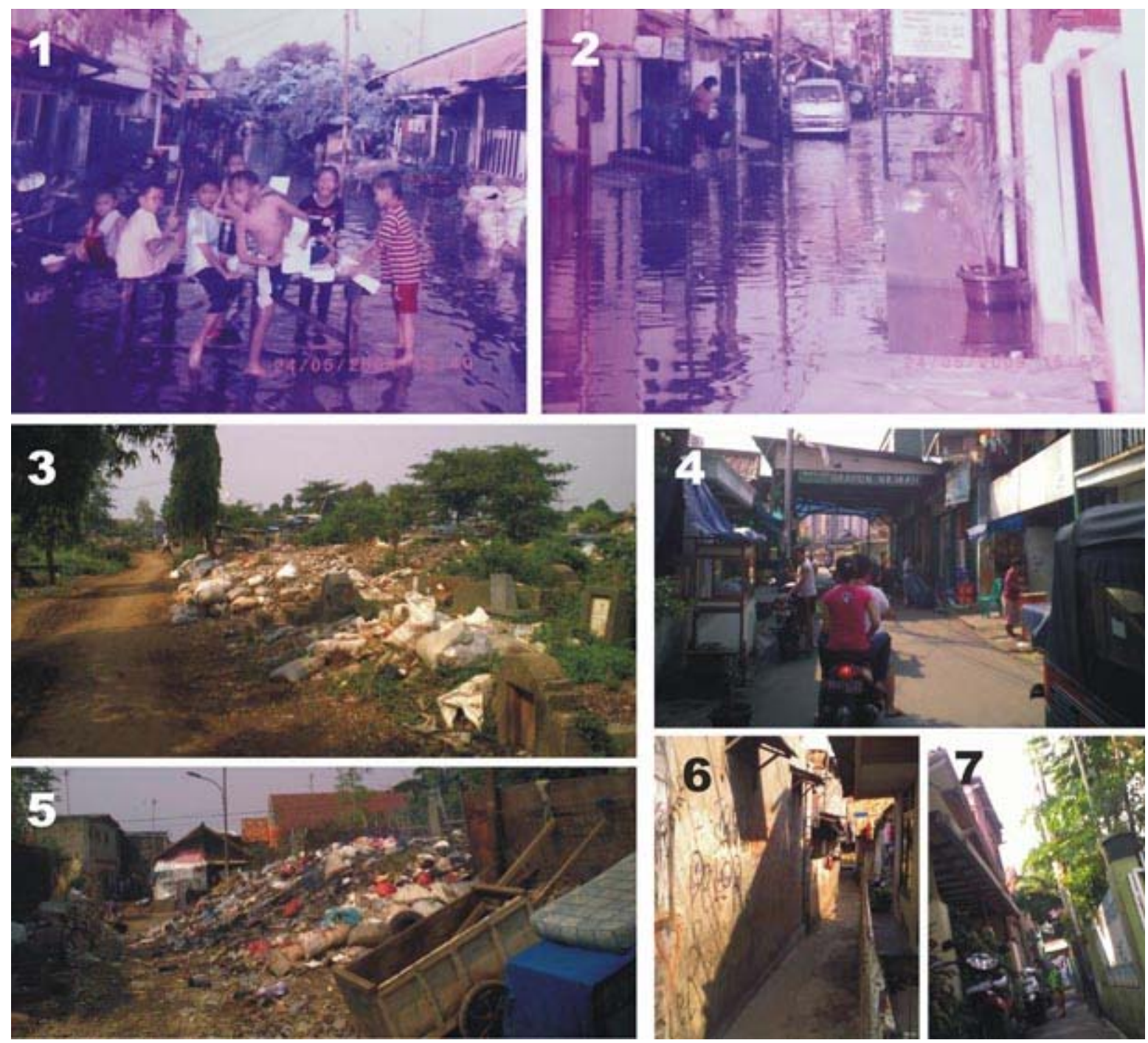

Fig. 2 Menteng Atas during rainy season (1 and 2), Illegal settlement (3 and 5), building density at Menteng Atas (4, 6, and 7).

Table 2 Garbage handling system and facilities at Kelurahan Menteng Atas.

\begin{tabular}{lcccc}
\hline RW & TPS & Location & Meet Requirement & Remarks \\
\hline 02 & None & - & - & Promptly transported by officials \\
\hline 04 & Available & Interactive Park RT.005 & Less & Transported by officials every 2-3 days \\
\hline 05 & None & - & - & Less carts number \\
\hline 06 & Available & Minangkabau Market & Less & Less carts number \\
\hline 07 & None & - & - & Promptly transported by officials \\
\hline 08 & None & - & - & Promptly transported by officials \\
\hline 09 & None & - & - & Less carts number \\
\hline 12 & Available & Empty land RT.010 & No & Transported by officials every 2-3 days \\
\hline 13 & Available & Kuburan Budha/Kristen & No & Un transported \\
\hline 14 & None & - & - & Less carts number \\
\hline 15 & Available & MCK RT. $003 \&$ Lapangan RT. 005 & No & Transported by officials every 2-3 days or more \\
\hline
\end{tabular}


Table 3 Result of physical environment, social and economic analysis.

\begin{tabular}{|c|c|c|c|}
\hline Location & Physical & Social & Economic \\
\hline RW 02 & 3 & 5 & 4 \\
\hline RW 04 & 3 & 4 & 4 \\
\hline RW 05 & 3 & 4 & 4 \\
\hline RW 06 & 3 & 5 & 5 \\
\hline RW 07 & 3 & 4 & 4 \\
\hline RW 08 & 3 & 5 & 4 \\
\hline RW 09 & 4 & 5 & 4 \\
\hline RW 12 & 4 & 5 & 4 \\
\hline RW 13 & 1 & 3 & 2 \\
\hline RW 14 & 3 & 5 & 4 \\
\hline RW 15 & 3 & 5 & 4 \\
\hline
\end{tabular}

From formulation of answers obtained, it can be concluded that the residents have not owned self-awareness toward disaster dangers which anytime may affect their area. They respond more to micro issues such as damaged path and need repair, water waterway is damaged and holed, and road light many are defunct/damaged and need points addition. They do not see access to their environment as narrow and winding among the building density as a problem that would obstruct them in case of fire. In answers obtained, obviously they do not see their residence as a part of community with larger scale (macro and multisectoral point of view). This is based on existence of housing and settlement which are inseparable and closely related to economic, industrialization and development activities. According to Jo Santoso [7], tendency of low income community to prefer their houses close to workplace or place to have opportunity for making housing and environment's physical quality is not important for them. Further Jo Santoso said the important thing for them is to day and not evicted.

Likewise toward the existing local institutional, they have not considered it as the potential they have. Existence of residential community and its activities at Menteng Atas is able to develop independently and run well. Among them are majlis ta'lim, womanhood such as arisan, PKK and Posyandu, sports activities, and the existence of cooperatives institutions in some neighborhood units. They considered all only as limited to routine activities which naturally exist in housing environment. From their answers on question what need they require related to the activities, they mention renovation and supporting facilities enhancement as needs they require. While trainings or other capacity building efforts are not priority in their answers. Arif and Bambang [8] have opinion that to build community's trust is the essence to create participation and activity sustainability. Institutional potential of Menteng Atas community indeed can be utilized as a driver to community development including in it flood and fire disaster anticipating and handling.

\section{Recommendations}

\subsection{Transportation Infrastructure}

Area of Menteng Atas needs primary local and secondary local road planning covering entire area of Menteng Atas. This primary local road is serving local transportation with short trip and low average speed. Minimum plan speed of $20 \mathrm{~km} /$ hours with ROW minimum $7 \mathrm{~m}$, so it can be reached by firefighting vehicles and ambulance, and garbage transport vehicles. Construction of these environment/primary local roads are designed such so entire area included in firefighting fire vehicles. This road may not be passed by public transportation, but it can be used for two-, three-, four-wheeled vehicles and pedestrians. While secondary local roads used in this area cover 2 types, namely secondary roads type I and type II. Secondary local roads type I is paths allotted for pedestrians and two-wheeled vehicles (taxi motor or bicycle) with ROW of $4.5 \mathrm{~m}$. But in particular condition, this road may be passed by ambulance car, firefighting trucks, and garbage trucks. Secondary local roads type II is paths which only used by bicycles or other two-wheeled vehicles and pedestrians with ROWN of $2.5 \mathrm{~m}$. 


\subsection{Flood Control and Drainage System}

Drainage planning which its finishing covers broader scale. Flood control plan is directed to normalization of existing macro waterway (particularly Dr. Sahardjo waterway located in arrangement location besides Cideng River in West side of location) with eviction of illegal buildings on rivers and develop vegetation permanently. In addition to macro waterway, secondary waterways going through areas of RW. 07, $08,09,13,14$, and 15 also need to receive attention and supervision. Elevation of flood-prone areas: Development of linking waterway is integrated with improvement and construction of collector and local roads. Tight security should be taken in macro waterways and link located in illegal buildings and garbage. The planning is also related with embankments along primary and secondary waterways which are damaged in some points. Waterway embankment damage also is one of main cause of inundation/flood in rainy season.

\subsection{Housing and Settlement Planning}

For permanent buildings especially with buiding age above 20 years, then the proposal is to renovate or repair with main target is adjustment with settlement building feasibility standard, relaed to classification of rooms, lighting, air circulation, and fire hazard prevention. If it is possible also conducting adjustment toward applicable urban regulations such as GSB, KDB, KLB, distance among buildings, etc. While semi permanent and non permanent buildings which are illegal buildings at location of Buddhist/Christian graveyard it is proposed to be rejunevated and adjusted with its original allotment. Plan of public facility land utilization by optimizing existing land as efficient as possible, by increasing quality and quantity of its building utilization. State land control should be priorized in its utilizaiton. In addition, public facilities are integrated with environmental rejunivication and improvement.

\subsection{Garbage Disposal and Environmental Sanitation System Plan}

Concept of garbage management proposed is by using garbage depot system placed at the center of settlement area (in each Community Unit). Garbage collection service from residents' houses using garbage cart, for further disposed to garbage depot. Garbage collected at garbage depot further disposed to Temporary Garbage Disposal Spot (TPS). Given the garbage management in Jakarta City which still relies on conventional system namely gathertransport-dispose system, resulting in not all garbage transported to TPA. One of things which can be carried out to ease burden in garbage handling in Jakarta is by reducing garbage volume both from source and at the garbage processing spot. Garbage recycle concept or usually referred to as 3R (Reduce, Reuse, and Recycle) is one of solutions to be considered, so economic value contained in the garbage can be capitalized on. Garbage processing following 3R concept may be conducted in integrated manner.

\subsection{Fire Handling System Planning}

In general there are two well-known fire handling systems, namely active protection system and passive protection system. In principle, fire handling prefers passive protection effort first, then conducting active protection efforts to handle fire. Both system, at their operating they handle fire simultaneously. But in their implementation it is natural if it would be difficult to facilitate all needs simultaneously and optimally. Let alone the communities themselves have various social classes and their own resistance level toward new things in their environment, which may hinder fire hazard prevention. Particularly concerning fire handling system, passive handling system is minimum handling system which its procurement is mandatory.

Path for fire protection at the housing environment should be planned such so water source is available in form of environment hydrant, fire well or water reservoir and so on which facilitating fire fighter 
institution to use them, so each house and building can be reached with water gush of fire fighting units from environment roads. Every building environment should be equipped with public communication facility which can be used any time to facilitate fire information report.

In order to conduct protection against spread of fire and facility firefighting operation, at the building environment there should be available environment roads with hardening so they can be passed by firefighting trucks. At each part of settlement building where the highest settlement floor height is measured from average ground does not exceeds $10 \mathrm{~m}$, then it is not require hardening layer expect it needs operational area of $4 \mathrm{~m}$ width along the building side where the access opening located, provided that the operational space can be reached in distance $45 \mathrm{~m}$ from firefighting truck access route.

In order to conduct protection against spread of fire, access route should be provided and determine distance between buildings, where for buildings less 8 floors requires distance between buildings of 3 meters (Kepmeneg PU. 10/2000). Each part of route for firefighting trucks at the building area should be in freeway of distance $50 \mathrm{~m}$ from city hydrant. If city hydrant is not available, then hydrant should be provided at yard. In situation requiring more than one yard hydrants, then the hydrants should be placed along firefighting trucks access route such, so each part of the route is in radius $50 \mathrm{~m}$ from hydrant. Water supply for yard hydrant should be at least 38 liters/second at pressure 3,5 bars, and is able to flow water minimum 30 minutes.

\subsection{Social Cultural Handling}

In urban development context economically and physically, then it is relatively very few experience which can be exhibited where community may play role as initiator of commercial efforts which can finance itself continously. Contributions obtained from high income residents/commercial are used up for environment's physical improvement than efforts to manage it as a capital for a larger activity.

Wheas as in fact there many reasons to argue about the necessity of community to have a role in commercial activity for self-reliance. This is apparent in the need to handle various things which without joint handling would result in high social costs such as: bad housing quality (health disturbances, low productivity, less employment and so forth), lack of education and health facilities, less job opportunities and income and so on.

By organizing self in cooperative way, the low income residents have a strong bargaining position to deal with expansion to its area. In this context the development of cooperative movement in community circle has goal with strategic dimension. This is realization of equal and just development concept which at the same time maintaining stability.

Dense settlement particularly in Jakarta never escapes from physical issues of area in form of flood and fire. If both are compared in dense settlement then the fire is most potential to be a disaster. Disaster urgency is in the threat of life victim in human and massive material loss. The hazard every time could become a serious threat for urban densely populated area. Then emerging question is how the physical vulnerability of area occurred in the settlement area.

Technical guidance covers efforts to minimize fire risks due to electronic equipments, caused by family activities to other negligence coming from human error operating in it. There is a tendency that slum settlement environment presents middle to low economic condition having implication to the low education level so it results in low concern level on safety in settlement. This tendency receives serious attention in technical guidance activities as it is related to develop communities' positive behavior in order to prevent fire. Besides to alert on fire hazards the residents are also asked in order that technically they are able to handle standard equipments which must be operated in case of fire. 
A Case Study of Menteng Atas - Jakarta, Indonesia

\section{References}

[1] Moh. Jehansyah Siregar, Belajar Dari Pengalaman Codi di Thailand., available online at: http://www.urbanpoor.or.id, February 2009.

[2] P. Healey, A. Khakee, A. Motte and B. Needham, Making Strategic Spatial Plans: Inno-vation in Europe, UCL Press, London, 1997.

[3] Rudito, Bambang and Melia Famiola, Social Mapping Metode Pemetaan Sosial; Teknik Memahami Suatu Masyarakat Atau Komuniti, Rekayasa Sains, Bandung, 2008.
[4] INRR (Institute of Natural and Regional Resources), Studi Etnografi dan Pemetaan Sosial, available online at: http://www.inrr.org, October 1, 2008.

[5] Stark, Rodney and Lynne Roberts, Con-temporary Social Research Method: A Text Using Micro Case, Wadsworth/Thomson Learning, Belmont, USA, 2002.

[6] Wirth Louis, Urbanisme as a way of life, in: Thomas Y. Cromwell, Urbanism in World Perspective, New York, 1968.

[7] Jo Santoso, Menyiasati Kota Tanpa Warga, KPG dan Centropolis, Jakarta, 2006.

[8] Arief Budimanta and Bambang Rudito, Metode dan Teknik Pengelolaan Commuity Development, ICSD, Jakarta, 2008. 